\title{
Climate change impact and adaptation on wheat yield, water use and water use efficiency at North Nile Delta
}

\author{
Marwa Gamal Mohamed Ali, Mahmoud Mohamed Ibrahim, Ahmed El Baroudy, Michael \\ Fullen, El-Said Hamad Omar, Zheli Ding \& Ahmed Mohammed Saad Kheir
}

\section{Abstract}

Investigating the potential impacts of climate change on food security is a major global concern, but there has been insufficient attention to these issues in arid regions. Therefore, two wheat models (DSSAT: CERES and N-Wheat) were calibrated with two local cultivars (Gemiza9 and Misr1) and baseline simulation (1981-2010) were compared with different scenarios of simulations using three Global Climate Models (GCMs) for 2030, 2050 and 2080. Probable impacts of climate change were assessed using three GCMs and the two crop models under the high emission Representative Concentration Pathway (RCP8.5). Results predicted decreased wheat grain yields by a mean of 8.7, 11.4 and 13.2\% in 2030, 2050 and 2080, respectively, relative to the baseline yield. Negative impacts of climatic change are likely, despite some uncertainties within GCMs (i.e. 2.1, 5 and $8 \%$ ) and CMs (i.e. 2.2, 6 and 9.2\%). Changing the planting date with a scenario of plus and minus 5 and 10 days from the common practice was assessed as a potential effective adaptation option and this may partially offset the negative impacts of climate change. Delaying the sowing date by 10 days (from 20 November to 30 November) was the best scenario decreased the further reduction in wheat yields resulting from climate change to 5.2, 6.8 and $8.5 \%$ in 2030, 2050 and 2080, respectively, compared with the 20 November scenario.. Early planting date scenario with 5 days had less effect on adapting climate change, meanwhile 10 days early scenario had negative effect, increasing yield reduction under climate change. The cultivar Misr1 showed higher resistance to rising temperature than Gemiza9. Despite the hazard impacts of climate change on wheat production, water use 
efficiency would slightly increase. The ensemble of multi-model estimated impacts and adaptation uncertainties of climate change can assist decision-makers in planning climate adaptation strategies.

Keywords DSSAT models, scenarios, adaptation, water use efficiency, climate change

\section{Introduction}

Egypt is considered one of the most vulnerable countries to climate change due to the extremely low rainfall (UNEP., 2010), as well as its dependence on the River Nile for irrigation water. Various global and regional climate change studies warn of the negative impacts on crop productivity, both globally (Wheeler and Von Braun, 2013), in Mediterranean region (Jeunessea et al., 2016), and in sub-Saharan Africa (Cairns et al., 2013b) with less attention in Egypt (Kheir et al., 2019). Several factors affect food security, including increased demand for wheat, rising input prices, soil degradation, greenhouse gases and the competition between land and water (Challinor et al., 2014; Pretty et al., 2010; Hertel, 2011).

Understanding the impacts of climatic parameters on food production is necessary to enable adaptation to the impacts of climate change (Asseng et al., 2015; Asseng et al., 2018b). Crop models can help to quantify climate change impacts and adaptation strategies and applied in many studies, including the assessment of temperature impacts on crop production (Rosenzweig et al., 2014) and protein (Asseng et al., 2019) rather than impacts of precipitation extremes (Piras et al., 2016). Ensemble multi-models are particularly useful tools to evaluate the impacts of climate change compared with individual models, as they can produce estimates that are as accurate as experimental data and offer the possibility to quantify levels of uncertainty (Wallach et al., 2018; Tao et al., 2018). The Decision Support System for Agro-technology Transfer (DSSAT) models (Jones et al., 2003) and the Agricultural Production Systems Simulator 
(APSIM) (Keating et al., 2003; Holzworth et al., 2014) are used globally and have commendable reputations. N-Wheat, formerly APSIM (Holzworth et al., 2014; Asseng et al., 1998) is a derivative crop model from CERES (Ritchie et al., 1998), but with additional modifications. These modifications include changes in crop water uptake systems and using water demand and biomass transpiration efficiency instead of Leaf Area Index (LAI) and potential evapotranspiration, as in CERES (Kassie et al., 2016). Such modifications could result in simulation differences between CERES-Wheat and N-Wheat models. N-Wheat had been included recently in DSSAT platform and not studied well before, and therefore used in current study. The role of technological diffusion processes in the environmental context, green economy and sustainable development is also evidenced (Aldieri and Vinci, 2017 and 2018; Hajek and Stejskal, 2018; Makkonen and Lnkinen, 2018). Climate change and variability have potentially negative impacts on crop production (Challinor et al., 2007b; Müller et al., 2011). These impacts are expected to increase globally (Thornton et al., 2010); and in Africa (Wheeler and Von-Braun, 2013), affecting global food security (Godfray et al., 2010), with relatively less attention requiring more further studies (Cairns et al., 2013a; Cooper and Coe, 2011). Further studies have reported that adaptation to climate change can decrease these impacts (Challinor et al., 2014; Rymbaia and Feroze, 2018; Swart et al., 2014). However, climate change adaptation has less attention in arid and semi-arid environments, particularly in small-scale holders (Mostegl et al., 2019).

Wheat (Triticum aestivum) is one of the most strategic crops in Egypt, however Egypt remains the world's largest importer country of wheat (Asseng et al., 2018). The understanding of climate models, downscaling ways and imperfect simulations within crop models are the main reasons for uncertainty (Asseng et al., 2013). While multiple climate scenarios and global 
climate models (GCMs) are widely used (Tebaldi and Knutti, 2007), single models with unknown uncertainties are also applied (Asseng et al., 2013). Therefore, we used two crop models and three GCMs within the Representative Concentration Pathway (RCP8.5) (Moss et al., 2010) to quantify the impacts of these scenarios on wheat yield. Therefore, the main objectives of this study were: (1) to calibrate and validate wheat crop models with two wheat cultivars grown in North Nile Delta region, (2) to investigate the impacts of climate change on wheat yield and water use efficiency on the Northern Nile Delta of Egypt, and (3) to explore changing planting dates plus and minus the common practice as potential adaptation options under different climate scenarios.

\section{Materials and Methods}

The current study includes two DSSAT models (CERES-Wheat and N-Wheat) calibrated for two wheat cultivars grown in field experiments through three successive growing seasons in Egypt. Then, the calibrated models were used to predict wheat yield, water use, and water use efficiency under different climate change scenarios include three GCMs and the higher emission scenario of representative concentration pathway (RCP8.5) and compared with baseline climate (19802010). To explore changing planting date as adaptation option, we changed planting date with a scenario of plus and minus 5 and 10 days from the common practice. Wheat yield was predicted under different climate scenarios using such planting dates by both models to explore the best planting date under climate change scenarios in different time series (2030, 2050 and 2080).

\subsection{The study area}

The study was conducted in large $\left(12.0 \mathrm{~m}^{3}\right)$ lysimeters $(1.5 \times 2.5 \mathrm{~m}$, height $3.0 \mathrm{~m})$ filled with non-saline clay soil since 1994 on the North Nile Delta of Egypt, Kafr El-Sheikh Governorate (KFS), Sakha; lat. 31.3-30.0 ${ }^{\circ} \mathrm{N}$, long. $31.0-31.3^{\circ} \mathrm{E}$; altitude $6 \mathrm{~m}$ above sea-level). The lysimeters were placed in an open field and surrounded with wheat to decrease the edge-effects produced by 
the lysimeters. The climate is characterized by a warm winter with a mean temperature $\sim 21.8^{\circ} \mathrm{C}$. Summer is hot with an average air temperature of $\sim 32.5^{\circ} \mathrm{C}$ and mean relative humidity is $\sim 65 \%$. Annual rainfall ranges from $100-150 \mathrm{~mm}$ and partially contributes to the water requirements of winter crops. The soil type is classified as a Vertic Torrifluvent (Said, 1993). The soil temperature regime is thermic, and the soil moisture regime is torric. The study site could be considered a representative for the whole region, including the first agroclimatic zone in Egypt $(30.0-31.0 \mathrm{~N})$. Initial soil analysis before cultivation is presented in Table 1.

\section{Table 1}

\subsection{Field treatments and practices}

A large lysimeter experiment was conducted at the Sakha Agricultural Research Station during three successive wheat growing seasons in 2015/2016, 2016/2017 and 2017/2018. The experiment included a split-plot design, with three replicates. To ensure genetic variability under current conditions, the main plots were assigned to two wheat cultivars. Gemiza9 is sensitive to higher temperatures and drought, while Misr1 is more resistant to both higher temperatures and drought (Asseng et al., 2018a; Ahmed et al., 2012). Wheat was sown on 20 November and harvested on 15 May in all growing seasons. The sub-plots were three irrigation treatments as a percent of soil moisture deficit (SMD). These were 35, 55 and 75\%, with the 55\% SMD treatment taken as the control. This value is representative of traditional farmer irrigation. Total seasonal evapotranspiration for both cultivars under different irrigation treatments is presented in supplementary Table.1. 


\subsection{DSSAT models calibration and evaluation}

Detailed yield and phenology parameters were measured. These included grain yield, total final biomass, anthesis date (DAS), maturity date (DAS), grain size, maximum Leaf Area Index (LAIx), nitrogen $(\mathrm{N})$ in grains (both $\%$ and $\mathrm{kg} / \mathrm{ha}$ ) and grain number per $\mathrm{m}^{2}$..

Both models were calibrated using the dataset of the 2015/2016 and validated using dataset of 2016/2017 and 2017/2018 growing seasons for Misr1 and Gemiza9 cultivars. The genetic parameters were changed manually in the calibration process to achieve the closest fit to observed data. The calibrated genetic parameters of both cultivars by CERES-Wheat and NWheat models are reported in Table 2. In calibration, the genetic parameters were incorporated in simple steps, with phenology first, then grain yield and biomass on the second step. The genetic coefficient of determination was calculated manually using the trial and error method (Godwin and Singh, 1998). The values were justified to achieve the minimum root mean square deviation (RMSD) between predicted and observed data. The initial values of each model parameter and values after calibration for both cultivars are presented in Table 2.

The goodness of fit between the measured and predicted data were calculated using several parameters: root mean square deviation, RMSD (Jacovides and Kontoyiannis, 1995), Willmott

Index of Agreement, WI (Willmott, 1984); and determination coefficient, $\mathrm{R}^{2}$ (Moriasi et al., 2007). Uncertainty of crop models and GCMs were calculated based on standard deviations and overall grain yield values.

\subsection{Climatic data}

Daily data of maximum and minimum temperatures, precipitation and solar radiation were obtained from the Central Laboratory of Agricultural Climate (CLAC) of Egypt (Fig. 1). The Sakha region is classified as the first Agro-ecological zone in Egypt and is characterized by a thermic soil temperature regime and a torric soil moisture regime (USDA, 2010). 


\section{Figure 1}

\subsection{Model simulations}

An ensemble of two wheat models CERES-Wheat and N-Wheat were calibrated and evaluated in this study. These models are involved in Decision Support Systems for Agrotechnology Transfer (DSSAT v, 4.7) (Hoogenboom et al., 2015; Jones et al., 2003). The choice of these models was based on their global reputation in climate change studies (Tubiello and Ewert, 2002). DSSAT crop models are designed to predict crop development and water use in response to soil characteristics, crop features, weather and management. Both models are calibrated and tested with Misr1 (Asseng et al., 2018) and Gemiza9 wheat cultivars for grain yield, total biomass, anthesis date and maturity date and applied hereafter to predict yield and water use under different climate scenarios.

\subsection{Climate change scenarios}

Daily measured weather data were collected by Central Laboratory of Agricultural Climate (CLAC) (www.clac.edu.eg) in Egypt and used for the simulation of field experiments. Daily baseline data (1981-2010) were abstracted from the NASA AgCFSR Climate Dataset: (http://data.giss.nasa.gov/impacts/agmipcf/) for the studied region without stress in either irrigation or fertilization. Three GCMs (GFDL-ESM2M, CSIRO-Mk3-6-0 and HadGEM2-ES) with one RCP (8.5) were prepared (Moss et al., 2010) for the years 2030, 2050 and 2080 using the 'delta method' (Wilby et al., 2004). The AgCFSR combines retrospective analyses, gridded meteorological station datasets and remotely-sensed radiation and precipitation information to form a coherent daily time series. The GCMs were selected based on their shifting projections of temperature and solar radiation. Plotting data show the range of temperature and solar radiation values under different GCMs and RCP8.5 through the $21^{\text {st }}$ Century (Fig. 2). RCP8.5 was selected based on assuming high concentrations of greenhouse gas emissions. In addition, it describes a 
pathway that has $8.5 \mathrm{~W} \mathrm{~m}^{-2}$ of radiative forcing by 2100 compared with the description of Van Vuuren (2011), which corresponds to pre-industrial concentrations. The $\mathrm{CO}_{2}$ concentrations for RCP8.5 were 432, 571 and $801 \mathrm{ppm}$ for 2030, 2050 and 2080, respectively, whereas the $\mathrm{CO}_{2}$ concentration for the baseline period was $360 \mathrm{ppm}$.

\section{Figure 2}

\subsection{The relative impacts}

The relative change in grain yield (GY), water use (ET) and water use efficiency (WUE) were calculated using the following equation:

$x=\frac{y \text { future }-y \text { baseline }}{y \text { baseline }}$

Water use efficiency (WUE) was calculated as follows:

$W U E=\frac{\text { SGY }}{\text { ET_Crop }}$

Here, SGY is the simulated grain yield $\left(\mathrm{kg} \mathrm{ha}^{-1}\right)$, and ET_Crop is the simulated cumulative evapotranspiration ( $\mathrm{mm}$ ) from sowing to maturity.

\subsection{Potential adaptation options}

We simulated changed planting dates as a potential adaptation option. Avoiding the current recommended planting date (20 November), scenarios of sowing plus and minus 5 and 10 days to $10,15,25$ and 30 November were chosen as adaptation options. Then, we simulated wheat yield under different climate scenarios and calculated change of predicted yield in four new planting dates relative to the current planting date.

\section{Results}

\subsection{Model calibrations and evaluations}

The methodology used to calibrate CERES-Wheat and N-Wheat proved successful (Fig. 3), attaining accurate predictions of grain yield, total biomass, anthesis date and maturity date. Wheat grain yield, biomass and phenology of both cultivars were suitably simulated by the 
DSSAT models, achieving lower RMSD and higher $\mathrm{R}^{2}$ and WI values (Table 3 and Fig. 3). However, simulating grain yield was the most crop growth parameter reproduced by the model very well.

Table 2

Figure 3

Table 3

\subsection{Projected changes in annual temperature}

The annual average maximum and minimum temperature for the baseline are 27.6 and $15.4^{\circ} \mathrm{C}$, respectively, with a mean of $21.5^{\circ} \mathrm{C}$. The overall minimum temperature is expected to increase by $0.7,1.0$ and $1.6^{\circ} \mathrm{C}$ in $2030 ; 2.0,2.5$ and $3.1^{\circ} \mathrm{C}$ in 2050 ; and $3.0,4.5$ and $4.9^{\circ} \mathrm{C}$ in 2080 for the three GCMs (CFDL-ES2M, CSIR0-MK3-6-0, and HadGEM2-ES), respectively (Fig. 4). Meanwhile, the increase in maximum temperature predicted by the three respective GCMs is $0.7,0.9$ and $1.7^{\circ} \mathrm{C}$ in the near decades (2030); 2.0, 2.3 and $3.0^{\circ} \mathrm{C}$ in the mid-century; and 3.1, 4.1 and $4.7^{\circ} \mathrm{C}$ in the late century (2080). Consequently, the annual mean temperature is expected to increase by $0.7,0.9$ and $1.6^{\circ} \mathrm{C}$ in $2030 ; 2.0,2.4$ and $3.0^{\circ} \mathrm{C}$ in 2050 ; and higher increases in 2080 of $3.0,4.3$ and $4.8^{\circ} \mathrm{C}$ for the three respective GCMs under RCP8.5 (Fig. 4).

\section{Figure 4}

\subsection{Impacts of climate change on wheat yield, water use, and water use efficiency}

The baseline (1981-2010) simulated mean yield of wheat was $9590 \mathrm{~kg} \mathrm{ha}^{-1}$ under optimum maturity growth without stress due to irrigation or fertilization treatments (Fig. 5A). Crop yield decreased under all climate scenarios relative to baseline yield (Fig. 5C). Crop and climate models demonstrate the mean wheat yield reduction of both cultivars relative to baseline yield (Fig. 5C). This reduction was calculated as $2.7,8.5$ and $14.9 \%$ in $2030 ; 8.4,9.5$ and $16.2 \%$ in 2050; decreasing markedly by $11.0,11.7$ and $17.0 \%$ in 2080 for GCM1, GCM2 and GCM3, 
respectively (Fig. 5C). Due to its higher resistance resulted from delayed anthesis and maturity (long growth duration), the cultivar Misr1 crop yield decreased less under future scenarios compared with Gemiza9. The relative mean wheat yield reduction for Misr1 under the three-time series of 2030, 2050 and 2080 was 8.3, 10.7 and 11.0\%, respectively. Meanwhile, for Gemiza9, the decrease was greater, at 9.0,11.7 and 15.7\%, respectively as an average of three GCMs (Fig. 5B). Consequently, the mean reduction of grain yield due to climate change for both cultivars was $8.7,11.4$ and $13.2 \%$ in 2030,2050 and 2080 respectively relative to baseline yield. The future growing periods for wheat under the climate scenarios were shorter than those in the baseline scenario (Table 4). The decrease was in the descending order: GCM1<GCM2<GCM3. The shortest growth period was predicted for 2080, followed by 2050 and then 2030 . Uncertainties in estimating yield impacts were relatively small at 2.3, 5 and $8 \%$ for GCMs for 2030, 2050 and 2080, respectively. For crop models (CMs), uncertainty was higher and recorded 2.5, 5.8 and 9.5\% than those in GCMs (Fig. 6). Since agriculture in Egypt is fully irrigated due to its low annual rainfall, crop water use, and water use efficiency are necessary factors. Water use had an adverse effect and decreased under future climate scenarios (Fig. 7), compared to grain yield (Fig. 5). Consequently, WUE increased under future climate scenarios (Fig. 8), despite increasing temperature through century.

\section{Figure 5}

\section{Figure 6}

Figure 7

\section{Figure 8}

\section{Table 4}

\subsection{Adaptation with changing planting dates}

The highest yield was under the optimum planting date (20 November) for the baseline climate (1981-2010) but decreased under future climate scenarios (Fig. 5A). Delaying the 
planting date decreased the yield reduction gap under future climate scenarios. Due to increasing temperatures under future climate decreasing yield, the future yield in 2030, 2050 and 2080 was predicted by postponing the planting date to 25 and 30 November, instead of the current recommended date of 20 November. Predicted grain yield reduction will be less under future climate scenarios through the $21^{\text {st }}$ Century due to postponed planting dates (Fig. 9). An assumed planting of 25 November partially decreased the predicted mean yield reduction of both cultivars caused by climate change to 4.8, 7.9 and $10.5 \%$ in 2030, 2050 and 2080, respectively (Fig. 9A). Changing planting date to 30 November was better in decreasing further reduction of yield particularly in 2050 and 2080, thus yield reduction decreased to 5.2, 6.8 and $8.5 \%$ in 2030, 2050 and 2080 respectively. Early planting date scenario with 5 days had a slight positive effect in three time periods, meanwhile early sowing with days had negative effects increasing yield reduction under climate change. The Misr1 cultivar achieved higher resistance to temperature than Gemiza9 with and without adaptations (Fig. 9B). The cause may be that later planting decreased heat stress at critical plant growth stages. Thus, delaying sowing by 5 and 10 days through the $21^{\text {st }}$ Century may partially offset yield reductions due to climate change.

\section{Figure 8}

\section{Discussion}

CERES-Wheat and N-Wheat crop models could be successfully used to select suitable cultivars and to investigate the impacts of climate change on wheat production. Wheat phenology has significant impacts on growth and development and thus plays a vital role in the calibration process (Ceglar et al., 2011). Model indices confirmed the accuracy of the model in simulating anthesis and maturity in spring wheat (Fig. 3, Table 3). In N-Wheat, anthesis and maturity dates were justified by VSEN, PPSEN, and P5, respectively (Table 2), thus emphasizing the importance of these parameters in the phenology calibration process (Asseng et al., 1998, 2013, 
2015). P1V, P1D, P5 and Phint are used to control and justify phenology in CERES-Wheat (Andarzian et al., 2015). Yet, changing P1, P2, P3 and P4 in the genotype file is required to enhance model accuracy and reduce uncertainty (Johnen et al., 2012). Accurate phenology is considered the first priority for model calibrations (Archontoulis et al., 2014). Ensuring high quality calibration of phenological parameters could help to accurately simulate yield, growth and biomass (Robertson et al., 2002). Biomass production could be controlled by solar radiative interception and radiative use efficiency. Our biomass production predictions proved to be highly accurate (Arora et al., 2007), due to the linear relationship between biomass and grain yield (Dettori et al., 2011). The STMMX and G3 parameters were used to calibrate biomass for both $\mathrm{N}$-wheat and CERES-Wheat, respectively (Table 2).

Grain yield is the result of dynamic interactions between crop canopy, radiation interception, radiation use efficiency and Harvest Index. Both models were highly robust in simulating grain yield. In N-Wheat, GRNO and MXFIL parameters were used to calibrate grain yield; while G1, G2 and G3 parameters were used for CERES-Wheat (Hunt and Boote, 1998). Grain and biomass calibration should follow the phenology calibration process (Ma et al., 2011). As a complex process, simulation modelling could be affected by soil, climate and crop variables, creating potential uncertainty (Kassie et al., 2016). Quantifying uncertainty by using a single crop model is problematic, particularly with climate change impacts on crop yield (Asseng et al. 2013; Rotter et al., 2011; Wallach et al., 2018). Uncertainty can be quantified with reasonable accuracy using ensemble multi-models (Martre et al., 2015), through expanding existing model platforms (Feng et al., 2014). Therefore, N-Wheat model, as a new derivative dynamic model recently added to current wheat models on the DSSAT platform (Kassie et al. 2016), was combined with CERES in this study. 
Although ensemble multiple models are valuable for decision-makers (Rosenzweig, 2013), like other models DSSAT models have limitations, particularly regarding effects of disease and pests on crop development. These limitations require more analysis and discussions in model simulations. During the past five decades, wheat yield in Egypt has steadily increased from 3.0 to 7.5 t/ha: http://www.fao.org/faostat/en/ due to technological advances. Our analysis of climate change scenarios on the Northern Nile Delta showed that future wheat yields will probably be negatively affected. Thus, food security in Egypt will deteriorate in a 'business as usual' scenario. Problems are compounded by increased population. Under the medium population growth scenario, the Egyptian population is expected to increase from 100 million in 2018 to 117 million in 2030, 151 million in 2060 and 187 million in 2080 (Roser and Ortiz-Ospina, 2017).

Projections of GCMs and climate change impacts generally result in some uncertainties (Fig. 9) (Osborne et al., 2013; Whitfield, 2013; Tao et al., 2018). Similarly, crop models, adaptation options and agricultural strategies involve uncertainty (Rötter et al. 2011; Rozenzweig et al. 2013; Tao et al., 2018). Climate change impacts on wheat yield under GCMs will be higher (-2.7 to $-14.9 \%),(-8.4$ to $-16.2 \%)$ and (-11.0 to $-17.0 \%)$ averaged over crop models for 2030,2050 and 2080, respectively, than between different crop models (-10.0 to $-14.0 \%),(-11.0$ to $-15.0 \%)$ and (-14.0 to $-18.0 \%)$ for the same three years (Fig 5B). Therefore, we can conclude that GCMs will generally dominate regional impact evaluations for the mid-century (2050) (Hawkins and Sutton 2011). However, these are predicted and not absolute values (Asseng et al. 2013; Rosenzweig et al. 2014)..

\section{Figure 9}

Decreased wheat yields in response to increasing temperature is mainly due to accelerating crop development and decreasing biomass and thus shortening of the crop life cycle (Asseng et 
al. 2015;Asseng et al., 2018; Sayre et al., 1997). Thus, there will be less solar radiation interception (Heng et al., 2007; Alexandrov and Hoogenboom, 2000). Water use efficiency increased despite the projected increase in temperature with climate change scenarios (Fig. 8), due to decreasing the total ET through growing season duration (Fig. 7). Decreasing ET under projected future climate is mainly due to shorter growth duration with higher temperatures and efficient transpiration from elevated $\mathrm{CO}_{2}$ concentrations (Asseng et al., 2018a; Deryng et al., 2016).

Changing sowing dates is one of the most widely adopted options to adapt cropping systems to climate change (White et al., 2011). According our findings, a later planting date will result in less crop loss than early and the current recommended sowing date in future climate scenarios. The current optimum sowing date may face a temperature increase at a critical growth stage; this could be avoided by delaying the sowing date. Rescheduling the planting date to 25 November decreased wheat yield loss under future climate by 3.9, 3.5 and 2.7\% for 2030, 2050 and 2080, respectively, relative to the current optimum sowing date in the baseline of 20 November (Fig. 9). These rates increased slightly to $3.5,4$ and $4.2 \%$ using the second planting date (30 November). This means the gap of yield reduction in response to future climate will probably decrease using this adaptation option. Results emphasize the critical importance of changing planting date as a potential adaptation option for climate change.

\section{Conclusions and research priorities}

Experimental and modelling studies were conducted on the North Nile Delta of Egypt. The study investigated the probable impacts of climate change on wheat yield and explored potential adaptation options. Attention focused on wheat, as it is one of the most important and strategic crops in Egypt. Different agronomic treatments included irrigation and two cultivars (Gemiza9 and Misr1) in three-successive wheat growing seasons (2015/2016, 2016/2017 and 2017/2018). 
Different climate change scenarios through the $21^{\text {st }}$ Century predicted yield using two crop models (CERES-Wheat and N-Wheat). Results from the models predicted yield decreases of 8.7, 11.4 and $13.2 \%$ as a mean value of the two cultivars in 2030,2050 and 2080 , respectively, relative to the baseline (1981-2010). These decreases are mainly attributed to increased temperatures shortening the wheat growing season. Potential adaptation options, such as delaying the planting date, could be used to counter the negative impacts of climate change. Such adaptations will probably decrease yield reduction gaps due to climate change. However, further adaptation strategies such as irrigation and fertilization management, plant density and row spacing will require major evaluations and subsequent major modifications to adaptation systems. Moreover, the adaptation options include considerable costs and require economic evaluations. Therefore, future research should include socio-economic evaluations of all viable adaptation options.

\section{Acknowledgments}

We thank the Agricultural Research Center; Soils, Water and Environment Research Institute (SWERI) for financial support. We are grateful to Dr Alex. C. Ruane (NASA Goddard Institute for Space Studies, New York, USA) for providing us with GCMs of the study area. Authors declare that there is no conflict of interest.

\section{References}

Ahmed M A, Magda A F, Ebtesam A E (2012). Growth and Yield Attributes of Some Newly Wheat Cultivars in Relation to Missing an Irrigation at Different Stages of Growth Journal of Applied Sciences Research, 8, 5075-5080.

Aldieri L, Vinci C P (2017). The role of technology splillovers in the processes of water poluution abatement for large international firms. Sustainability, 9 (5), 868.

Aldieri L, Vinci C P (2018). Green economy and sustainable development: the economic impact of innovation on employment. Sustainability, 10, 3541. 
Alexandrov V A, Hoogenboom G (2000). The impact of climate variability and change on crop yield in Bulgaria. Agric. For. Meteorol. , 104, 315-327.

Andarzian B, Hoogenboom G, Bannayan M, Shirali M, Andarzian B (2015). Determining optimum sowing date of wheat using CSM-CERES-Wheat model. J.Saudi. Soc. Agri. Sci., 14, 189-199.

Archontoulis S V, Miguez F E, Moore K J (2014). A methodology and an optimization tool to calibrate phenology of short-day species included in the APSIM PLANT model: application to soybean. Environ. Modell. Softw, 62, 465-477.

Arora V K, Singh H , Singh B (2007). Analyzing wheat productivity responses to climatic, irrigation and fertilizer-nitrogen regimes in a semi-arid sub-tropical environment using the CERES-Wheat model. Agric. Water Manage, 94, 22-30.

Asseng S, Ewert F, Martre P, Rotter R P, Lobell D B, Cammarano D, Kimball B A, Ottman M J, Wall G W, White J W, Reynolds M P, Alderman P D, Prasad P V V, Aggarwal P K, Anothai J, Basso B, Biernath C, Challinor A G, DE sanctis G, Doltra J, Fereres E, Garcia-vila M, Gayler S, Hoogenboom G, Hunt L A, Izaurralde R C, Jabloun M, Jones C D, Kersebaum K C, Koehler A K, Muller C, Naresh kumar S, Nendel C, Leary G O, Olesen J E, Palosuo T, Priesack E, Eyshi rezaei E, Ruane A C, Semenov M A, Shcherbak I, Stockle C, Stratonovitch P, Streck T, Supit I, Tao F, Thorburn P J, Waha K, Wang E, Wallach D, Wolf J, Zhao Z, Zhu Y (2015). Rising temperatures reduce global wheat production. Nat Clim Change, 5, 143-147.

Asseng S, Ewert F, Rosenzweig C, Jones J W, Hatfield J L, Ruane A C, Boote K J, Thorburn P J, Rooter R P, Cammarano D, Brisson N, Basso B, Martre P, Aggarwal P K, Angulo C, Bertuzzi P, Biernath C, Challinor A G, Doltra J, Gayler S, Goldberg R, Grant R, Heng L, Hooker J, Hunt L A, Ingwersen J, Izaurralde R C, Kersebaum K C, Muller C, Naresh kumar S, Nendel C, O’leary G, Olesen J E, Osburne T M, Palosuo T, Priesack E, Ripoche D, Semenov M A, Shcherbak I, Steduto P, Stockle C, Stratonovitch P, Streck T, Supit I, Tao F, Travasso M, Waha K, Wallach D, White J W, Williams J R, Wolf J (2013). Uncertainty in simulating wheat yields under climate change. Nat Clim Change, 3, 827832.

Asseng S, Keating B A, Fillery I R P, Gregory P J, Bowden J W, Turner N C, Palta J A, Abrecht D G (1998). Performance of the APSIM-wheat model in western Australia? . Field Crops Res, 57, 163-179.

Asseng S, Kheir A M S, Kassie B T, Hoogenboom G, Abdelaal A I N, Haman D Z, Ruane A C (2018). Can Egypt become self-sufficient in wheat? Environ. Res. Lett., 13, https://doi.org/10.1088/1748-9326/aada50.

Asseng S, Martre P, Maiorano A, Rötter R P, O’leary G J, Fitzgerald G J, Girousse C, Motzo R, Giunta F, Babar M A, Reynolds M P, Kheir A M S, Thorburn P J, Waha K, Ruane A C, Aggarwal P K, Ahmed M, Balkovič J, Basso B, Biernath C, Bindi M, Cammarano D, Challinor A J, DE sanctis G, Dumont B, Eyshi rezaei E, Fereres E, Ferrise R, Garcia-vila M, Gayler S, Gao Y, Horan H, Hoogenboom G, Izaurralde R C, Jabloun M, Jones C D, Kassie B T, Kersebaum K C, Klein C, Koehler A K, Liu B, Minoli S, Montesino san martin M, Müller C, Naresh kumar S, Nendel C, Olesen J E, Palosuo T, Porter J R, Priesack E, Ripoche D, Semenov M A, Stöckle C, Stratonovitch P, Streck T, Supit I, Tao F, Van der velde M, Wallach D, Wang E, Webber H, Wolf J, Xiao L, Zhang Z, Zhao Z, Zhu Y, Ewert F (2019). Climate change impact and adaptation for wheat protein. Global Change Biology, 25, 155-173. 
Cairns J E, Hellin J, Sonder K, Araus J L, Macrober J F, Thierfelder C , Prasanna B M (2013). Adapting maize production to climate change in sub-Saharan Africa. Food Security 5, 345-360.

Ceglar A C, Repinšek Z, Kajfež-bogataj L, Pogačar T (2011). The simulation of phenological development in dynamic crop model: the Bayesian comparison of different methods. Agric. For. Meteorol, 151, 101-115.

Challinor A G, Watson J, Lobell D B, Howden S M, Smith D R, Chhetri N (2014). A metaanalysis of crop yield under climate change and adaptation. Nat Clim Change 4, 287-291.

Challinor A G, Wheeler T, Garforth C, Crauford B , Kassam A (2007). Assessing the vulnerability of food crop systems in Africa to climate change. Clim Chang 83, 381-399.

Cooper P J M , Coe R (2011). Assessing and addressing climate-induced risk in sub-Saharan rainfed agriculture. Exp Agric 47:179.

Deryng D, Elliott J, Folberth C, Müller C, Pugh T A M, Boote K J, Conway D, Ruane A C, Gerten D, Jones J W, Khabarov N, Olin S, Schaphoff S, Schmid E, Yang H, Rosenzweig C (2016). Regional disparities in the beneficial effects of rising CO2 concentrations on crop water productivity Nature Climate Change, 6, 786-790.

Dettori M, Cesaraccio C, Motroni A, Spano D, Duce P (2011). Using CERES-Wheat to simulate durum wheat production and phenology in Southern Sardinia. Field Crop Res, 120, 179188.

Feng Z, Yao Y, Huilong C, Feng Y (2014). Reusable component model development approach for parallel and distributed simulation. Sci. World J.

Godfray H C J, Beddington J R, Crute I R, Haddad L, Lawrence D, Muir J F, Pretty J, Robinson S, Thomas S M , Toulmin C (2010). Food Security: The Challenge of Feeding 9 Billion People. Science, 327, DOI: 10.1126/science.1185383.

Godwin D C, Singh U (1998). Nitrogen balance and crop response to nitrogen in upland and lowland cropping systems . In: Tsuji, G., Hoogenboom, G., Thornton, P. (Eds.), . Understanding Options for Agricultural Production. Springer, Netherlands, , 55-77.

Hajek P, Stejskal J (2018). R\&D cooperation and knowledge spillover effects for sustainable business innovation in the chemical industry. Sustainability, 10(4), 1064.

Heng L K, Asseng S, Mejahed K, Rusan M (2007). Optimizing wheat productivity in two rainfed environments of the West Asia-North Africa region using a simulation model. Eur. $J$. Agron, 26, 121-129.

Hertel T W (2011). The global supply and demand for agricultural land in 2050: A perfect storm in the making? Amer. J. Agr. Econom, 93, 259-275.

Holzworth D P, Huth N I, Devoil P G, Zurcher E J, Herrmann N I, Mclean G, Chenu K, Van oosterom E J, Snow V, Murphy C, Moore A D, Brown H, Whish J P M, Verrall S, Fainges J, Bell L W, Peake A S, Poulton P L, Hochman Z, Thorburn P J, Gaydon D S, Dalgliesh N P, Rodriguez D, Cox H, Chapman S, Doherty A, Teixeira E, Sharp J, Cichota R, Vogeler I, Li F Y, Wang E L, Hammer G L, Robertson M J, Dimes J P, Whitbread A M, Hunt J, Van rees H, Mcclelland T, Carberry P S, Hargreaves J N G, Macleod N, Mcdonald C, Harsdorf J, Wedgwood S, Keating B A (2014). APSIM evolution towards a new generation of agricultural systems simulation. Environ. Modell. Software, 62, 327-350.

Hoogenboom G, Jones J W, Wilkens P W, Porter C H, Boote K J, Hunt L A, Singh U, Lizaso J I, White J W, Uryasev O, Ogoshi R, Koo J, Shelia V, Tsuji G Y (2015). Decision Support 
System for Agrotechnology Transfer (DSSAT) Version 4.6 (www.DSSAT.net). DSSAT Foundation, Prosser, Washington.

Hunt L A, Boote K J (1998). Data for model operation, calibration, and evaluation. In: Tsuji, G., Hoogenboom, G., Thornton, P. (Eds.),. Understanding Options for Agricultural Production. Springer, Netherlands, 9-39.

Jacovides C P, Kontoyiannis H (1995). Statistical procedures for the evaluation of evapotranspiration computing models. Agricultural Water Management 27, 365-371.

Jeunessea I L, Cirelli D, Aubin D, Larru C, Sellami H, Afifif S, Bellin A, Benabdallah S, Birdi D N, Deidda R, Dettori M, Engin G, Herrmann F, Ludwig R, Mabrouk B, Majone B, Paniconi C, Soddu A (2016). Is climate change a threat for water uses in the Mediterranean region? Results from a survey at local scale. Science of The Total Environment, 543, 981-996.

Johnen T, Boettcher U, Kage H (2012). A variable thermal time of the double ridge to flag leaf emergence phase improves the predictive quality of a CERES-Wheat type phenology model. Comput. Electr. Agric, 89, 62-69.

Jones J W, Hoogenboom G, Porter C H, Boote K J, Batchelor W D, Hunt L A, Wilkens P W, Singh U, Gijsman A J, Ritchie J T (2003). The DSSAT cropping system model. Eur. J. Agron, 18, 235-265.

Kassie B T, Asseng S, Porter C H, Royce F S (2016). Performance of DSSAT N-Wheat across a wide range of current and future growing conditions Europ. J.Agronomy, 81, 27-36.

Keating B A, Carberry P S, Hammer G L, Probert M E, Robertson M J, Holzworth D, Huth N I, Hargreaves J N G, Meinke H, Hochman Z, Mclean G, Verburg K, Snow V, Dimes J P, Silburn M, Wang E, Brown S, Bristow K L, Asseng S, Chapman S, Mccown R L, Freebairn D M, Smith C J (2003). An overview of APSIM: a model designed for farming systems simulation. Eur.J. Agron, 18, 267-288.

Kheir A M S, El baroudy A A, Aiad M M, Zoghdan M G, Abd el-aziz M A, Ali M G M, Fullen M (2019). Impacts of rising temperature, carbon dioxide concentration and sea level on wheat production in North Nile delta. Science of The Total Environment, 651, 3161-3173.

Makkonen T and Lnkinen T (2018). Sectoral and technological systems of environmental innovation: The case of marine scrubber systems. Journal of Cleaner Production, 200, 100-120.

Ma L, Ahuja L R, Saseendran S A, Malone R W, Green T R, Nolan B T, Bartling P N S, Flerchinger G N, Boote K J, Hoogenboom G (2011). A Protocol for Parameterization and Calibration of RZWQM2 in Field Research. In: Ahuja, L.R., Ma, L. (Eds.). Methods of Introducing System Models into Agricultural Research. Am Society Agron, Crop Science Society of America, Soil Science Society of America, 1-64.

Martre P, Wallach D, Asseng S, Ewert F, Jones J, Rotter R, Boote K, Ruane A C, Thorburn P, Cammarano D, Hatfield J, Rosenzweig C, Aggarwal P, Angulo C, Basso B, Bertuzzi P, Biernath C, Brisson N, Challinor A, Doltra J, Gayler S, Goldberg R, Grant R, Heng L, Hooker J, Hunt L, Ingwersen J, Izaurralde R, Kersebaum K, Muller C, Kumar S, Nendel C, O'leary G, Olesen J, Osborne T, Palosuo T, Priesack E, Ripoche D, Semenov M, Shcherbak I, Steduto P, Stockle C, Stratonovitch P, Streck T, Supit I, Tao F, Travasso, M, Waha K, White J, Wolf J (2015). Multimodel ensembles of wheat growth:many models are better than one. Global Change Biol, 21, 911-925. 
Moriasi D N, Arnold J G, Liew M W V, Bingner R L, Harmel R D, Veith T L (2007). Model evaluation guidelines for systematic quantification of accuracy in watershed simulations. Transactions of the ASABE, 50, 885-900.

Moss R H, Edmonds J A, Hibbard K A, Manning M R, Rose S K, Van vuuren D P, Carter T R, Emori S, Kainuma M, Kram T, MeehL G A, Mitchell J F B, Nakicenovic N, Riahi K, Smith S J, Stouffer R J, Thomson A M, Weyant J P, Wilbanks T J (2010). The next generation of scenarios for climate change research and assessment. Nature, 463, 747756.

Mostegl N M, Pröbstl-haider U, Jandl R, Haider V (2019). Targeting climate change adaptation strategies to small-scale private forest owners. Forest Policy and Economics, 99, 83-99.

Müller C, Cramer W, Hare W L, Lotze-campen H (2011). Climate change risks for African agriculture. Proc Natl Acad Sci 108, 4313-4315.

Osborne T, Rose G, Wheeler T (2013). Variation in the global-scale impacts of climate change on crop productivity due to climate model uncertainty and adaptation. Agric For Meteorol, 170, 183-194.

Piras M, Mascaro G, Deiddaa R, Vivoni E R (2016). Impacts of climate change on precipitation and discharge extremes through the use of statistical downscaling approaches in a Mediterranean basin. Science of The Total Environment, 543, 952-964.

Pretty J, Sutherland W J, Ashby J, Auburn J, Baulcombe D, Bell M, Bentley J, Bikerstesth S, Brown K, Burke J, Campbell H, Chen K, Crowley E, Crute I, Dobelaere D, Edwardsjones G, Funes-monzote F, Godfray H C J, Griffon M, Gypmantisiri P, Haddad L, Halavatau S, Herren H, Holderness M, Izac A, Jones M, Koohafkan P, Lal R, Lang T, Mcneely J, Mueller A, Nisbett N, Noble A, Pingali P, Pinto Y, Rabbinge R, Ravindranath N H, Rola A, Roling N, Sage C, Settle W, Sha J M, Shiming L, Simons T, Smith P, Strzepek K, Swaine H, Terry E, Tomich T P, Toulmin C, Trigo E, Twomlow S, Vis J K, Wilson J, Pilgrim S (2010). The top 100 questions of importance to the future of global agriculture. Int. J. Agr. Sustain, 8, 219-236.

Ritchie J T, Singh U, Godwin D, Bowen W T (1998). Cereal growth, development,and yield. In: Tsuji, G.Y., Hoogenboom, G., Thornton, P.K. (Eds.), Understanding Options for Agricultural Production. The Netherlands: Kluwer Academic, Dordrecht, 79-98.

Robertson M J, Carberry P S, Huth N I, Turpin J E, Probert M E, Poulton P L, Bell M, Wright G C, Yeates S J, Brinsmead R B (2002). Simulation of growth and development of diverse legume species inAPSIM. Aust. J. Agric. Res, 53, 429-446.

Rosenzweig C, Elliott J, Deryng D, Ruane A C, Muller C, Ameth A, Boote K J, Folberth C, Glotter M, Khabarov N, Nuemann K, Piontek F, Pugh T A M, Schmid E, Stefhest E, Yang H, Jones J W (2014). Assessing agricultural risks of climate change in the 21st century in a global gridded crop model intercomparison. Proc. Natl Acad. Sci, 111, 32683273.

Rosenzweig C E A (2013). The agricultural model intercomparison and improvement project (AgMIP): protocols and pilot studies. Agric For Meteorol, 170, 166-182.

Rotter R P, Carter T R, Olesen J E, Porter J R (2011). Crop-climate models need an overhaul? . Nat. Clim. Change, 1, 175-177.

Rymbaia D, Feroze S M (2018). The insight of agricultural adaptation to climate change: A case of rice growers in Eastern Himalaya,India. Int J Biometeorol, 62, doi: 10.1007/s00484018-1586-3. 
Sayre K D, Rajaram S, Fischer R A (1997). Yield potential progress in short bread wheats in Northwest Mexico. Crop Sci., 37, 36-42.

Swart R, Biesbroek R, Lourenço T C (2014). Science of adaptation to climate change and science for adaptation. Fronteirs in Environmental Science, 2, doi: 10.3389/fenvs.2014.00029.

Tao F, Rötter R P, Palosuo T, Gregorio hernández díaz-ambrona C, Mínguez M I, Semenov M A, Kersebaum K C, Nendel C, Specka X, Hoffmann H, Ewert F, Dambreville A, Martre P, Rodríguez L, Ruiz-ramos M, Gaiser T, Höhn J G, Salo T, Ferrise R, Bindi M, Cammarano D, Schulman A H (2018). Contribution of crop model structure, parameters and climate projections to uncertainty in climate change impact assessments. Glob Chang Biol, 24, 1291-1307. doi: 10.1111/gcb.14019.

Tebaldi C, Knutti R (2007). The use of the multi-model ensemble in probabilistic climate projections. Math Phys Eng Sci 365, 2053-2075.

Thornton P K, Jones P G, Alagarswamy G, Andresen J, Herrero M (2010). Adapting to climate change: agricultural system and household impacts in East Africa. Agric Syst 103, 73-82.

Tubiello F N, Ewert F (2002). Simulating the effects of elevated CO2 on crops: approaches and applications for climate change. Eur J Agron, 18, 57-74.

Unep (2010). Africa Water Atlas. Division of Early Warning and Assessment United Nations Environment Programme, Nairobi, Kenya.

Wallach D, Martre P, Liu B, Asseng S, Ewert F, Thorburn P J, Van ittersum M, Aggarwal P K, Ahmed M, Basso B, Biernath C, Cammarano D, Challinor A G, De sanctis G, Dumont B, Eyshi rezaei E, Fereres E, Tzgerald G J, Gao Y, Garcia-vila M, Gayler S, Girousse C, Hoogenboom G, Horan H, Izaurralde R C, Jones C D, Kassie B T, Kersebaum K C, Klein C, Koehler A K, Maiorano A, Minoli S, Müller C, Naresh kumar S, Nendel C, O’leary G K, Palosuo T, Priesack E, Ripoche D, Rötter R P, Semenov M A, Stöckle C, Stratonovitch P, Streck B, Supit I, Tao F, Wolf J, Zhang Z (2018). Multi-model ensembles improve predictions of crop-environment-management interactions. Global Change Biology, doi: 10.1111/gcb.14411.

Wheeler T, Von braun J (2013). Climate change impacts on global food security. Science, 341, $508-513$.

White J W, Hoogenboom G, Kimball B A, Wall G W( 2011). Methodologies for simulating impacts of climate change on crop production. Field Crop Res 124, 357-368.

Whitfield S (2013). Uncertainty, ignorance and ambiguity in crop modelling for African agricultural adaptation. Clim Chang, 1-16.

Wilby R, Charles S P, Zorita E, Timbal B, Whetton P, Mearns L O (2004). Guidelines for use of climate scenarios developed from statistical downscaling methods. IPCC task group on data and scenario support for impacts and climate analysis.

Willmott C J (1984). On the evaluation of model performance in physical geography. In Spatial Statistics and Models, Gaile GL, Willmott CJ (eds). D. Reidel: Boston, 443-460. 


\section{Figure Captions}

Fig. 1. Daily maximum temperature (dashed red lines), minimum temperature (dashed green lines), solar radiation (balck lines) and precipitation (blue bars) at Sakha during three growing seasons $(2015 / 2016,2016 / 2017$ and 2017/2018).

Fig. 2. The relative changes of Daily solar radiation, maximum temperature and minimum temperature to baseline under RCP8.5 and three global climate models (GCMs) during the $21^{\text {st }}$ Century.

Fig. 3. Calibrations and validation of N-Wheat (black closed circles) and CERES-Wheat (open circles) models under different irrigation treatments for two cultivars (Gemiza9 and Misr1) in three growing seasons on the North Nile Delta.

Fig. 4. Change of daily maximum and minimum temperature relative to the baseline (1981-2010) under three GCMs and RCP8.5 through the $21^{\text {st }}$ Century.

Fig. 5. Grain wheat yield (A), relative change (B) compared with the baseline (1981-2010) for both cultivars, open bars (Gemiza9) and closed bars (Misr1) and average relative change of both cultivars (C) using two crop models (CMs) and three GCMs and RCP8.5 through the $21^{\text {st }}$ Century under current planting date (20 November) without adaptation.

Fig. 6. Uncertainty of CMs and GCMs. Uncertainties are relative standard deviations based on two CMs (N-Wheat and CERES-Wheat) and three GCMs. Fig. 7. Accumulation seasonal evapotranspiration in baseline, short, mid and end of century (above), as well as under different GCMs (below). Fig. 8. Water use efficiency in baseline, short, mid and end of century (above), as well as under different GCMs (below). .

Fig. 9. Relative grain yield reduction (\%) to baseline in different time series (A, above), without adaptation and with adaptations A (delay sowing date by 5 days), adaptation B (delay sowing date by 10 days), adaptation $\mathrm{C}$ (early sowing by 5 days), and adaptation $\mathrm{D}$ (early sowing by 10 days) and relative grain yield reduction (\%) to baseline for both cultivars under four adaptation options in 2030, 2050 and 2080 (B, below). 